\title{
Patterns of Association between Marine Sponges and the Associated Organisms: Case Study, Losin Island, Pattani, Thailand
}

\section{Udomsak DARUMAS ${ }^{1, *}$, Supaporn PHASOMBUN ${ }^{1}$ and Ratchanee PUTTAPREECHA ${ }^{2}$}

\author{
${ }^{1}$ Division of Biology, School of Science, Walailak University, Nakhon Si Thammarat 80160, Thailand \\ ${ }^{2}$ Marine and Coastal Resources Research and Development Center Lower Gulf of Thailand, \\ Songkhla 90100, Thailand
}

("Corresponding author's e-mail: dudomsak@mail.wu.ac.th)

Received: 10 March 2018, Revised: 21 November 2018, Accepted: 18 December 2018

\begin{abstract}
Ko Losin, the southernmost offshore islet in the Gulf of Thailand is one of the most naturally, less anthropogenic disturbed coral reefs in Thailand and the home of the major sessile organisms: corals and sponges. This study aims to investigate the natural patterns of association (interactions) between marine sponges and the associated organisms. The types of interaction were classified into 4 categories: Gap, Overgrown, Tissue contact, and Overgrow. The investigation focused on four genera of sponges: Chondrilla, Hyrtios, Cinachyrella, and Xestospongia. Chondrillid sponge showed the high frequency of inhabiting associated organisms. Some hermatypic corals such as Montiporian corals and Porites corals were highly proportioned to the associated organisms. The gap and overgrown interactions were recorded in this study.
\end{abstract}

Keywords: Chondrilla, Cinachyrella, Hyrtios, Xestospongia, Gap, Overgrown, Overgrow, Tissue contact

\section{Introduction}

Generally, space is one of the limited resources in marine ecosystem, particularly coral reef ecology. Such a limited resource often leads to competition for space among sessile organisms (such as Algae, sponges (Porifera), corals (Cnidaria), moss animal (Bryozoa), and sea squirt (Chordata). Corals are considered as the major groups of sessile animals, which occupy the reefs. However, some coral reefs are not dominated by corals, but sponges [1]. Sponges are expected to be the potential competitors for corals in many places such as NE Columbia and Puerto Rico [2,3]. Being the potential competitor for space, sponges need to have various abilities/mechanisms/tactics in order to lead the competition. Cliona delitrix bores and destructs the colony of Montrastrea coral [1]. Likewise, Desmapsamma anchorata, Dysidea janiae and Iotrochota birotulata overgrow/smoother species of gorgonians [4]. However, it cannot be concluded that the sponge density is related to the coral coverage area due to competition interaction. In the Wakatubi Marine national park in Indonesia, sponge density showed positive yet weak relationship with regard to its percentage of hard coral cover. Additionally, sponge densities seem to vary from site to site, when the influence of environmental variability is discussed [5]. The mechanisms of competition are mechanically and/or chemically unique to species of organisms. Acontarian sea anemone (Exaiptasia pallida) uses thread loaded with nematocyst batteries, known as acontia to defend themselves [6]. Sponges have been known to be as the aggressive space competitor for reef building corals and other coral organisms [2,7]. Studies reported that some sponge genera, (such as Chondrilla, Hemectyon, Ircinia and Verongia) are more aggressive in the deeper water of the Caribbean coral reef community. They overgrow corals gorgonians and other sponges [2]. On the contrary, sponge (Agelus conifer) is observed 
http://wjst.wu.ac.th

to be overgrown by lettuce coral (Halioseris cucullata) with uninvestigated mechanisms [8]. However, competition between sponge and algae are complex with regard to nutrient levels in water column; shading; abrasion and; allelopaty [9]. Sponge's mechanisms to compete with competitors varies. Furthermore, secondary metabolites of sponge are known to be an anti-predator as well as allelopathy to some coral competitors [10]. Morphologically, sponges are capable of plastic morphology to overgrowth, epizoism other associated organisms $[1,11,12]$. In addition, the interference interactions between sponges and corals have been classified as over growth, peripheral contact, tissue contact and non-contact interactions [3]. The interference interactions of sponges with associated organisms are useful to understand the hierarchical levels or the complexity role of sponges in inhibiting the community. The objective of this study is to investigate the proportion of interference interactions between sponges and associate organism at Ko Losin.

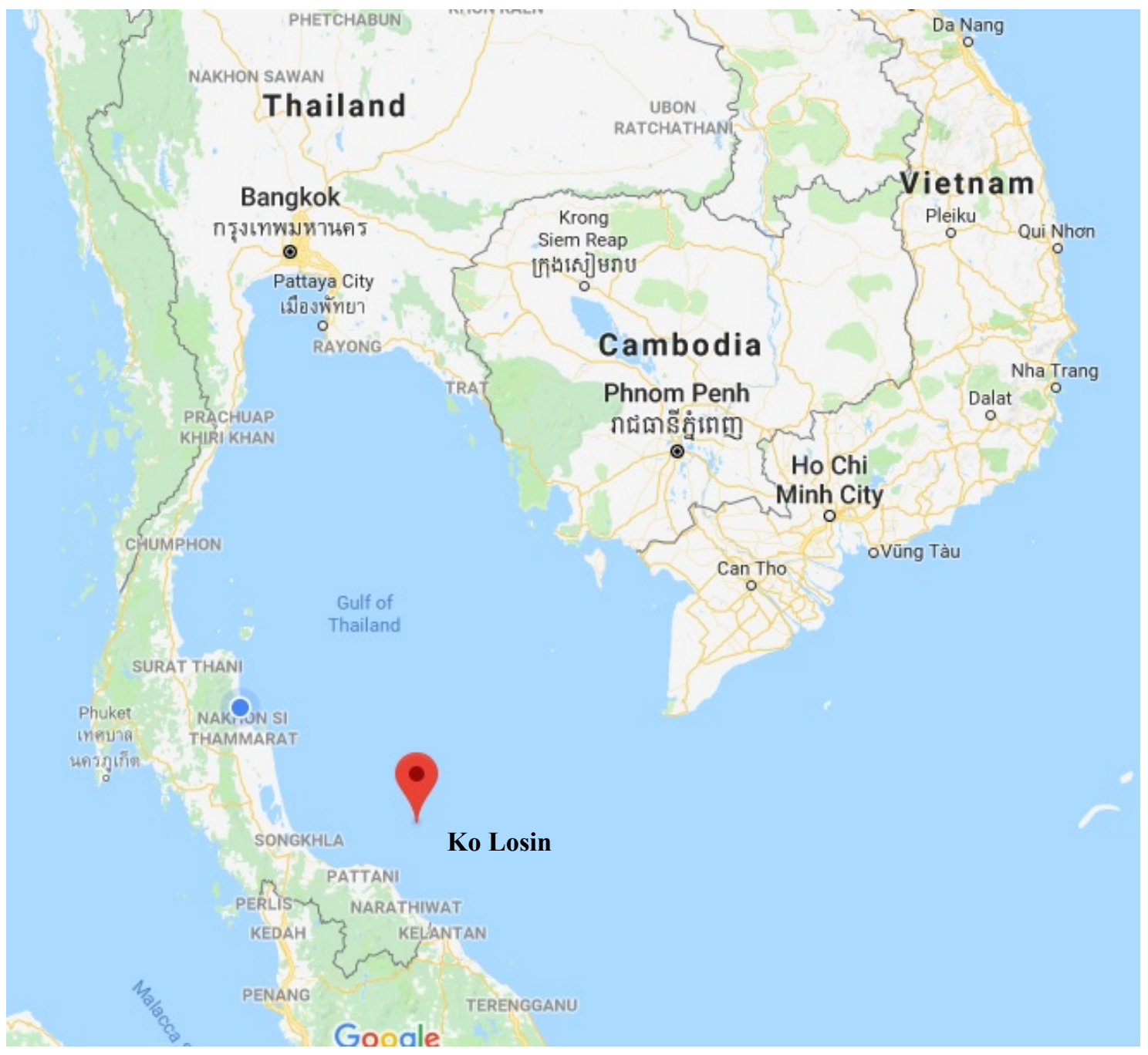

Figure 1 Location of Ko Losin. 


\section{Materials and methods}

\section{Site description}

Ko Losin, the southernmost islet of Thailand, has been published in Government Gazette as a sea boundary of Thailand (Government Gazette, 1992). It is located on $7^{\circ} 19^{\prime} 54^{\prime \prime} \mathrm{N}, 101^{\circ} 59^{\prime} 54^{\prime}$ ' E. It is about $153 \mathrm{~km}$ east of Songkla province and is about $64 \mathrm{~km}$ northeast of Pattani province (Figure 1). Ko Losin appears as a small rock in the open sea (southern of the Gulf of Thailand). The above sea level area is about several hundred square meters and its averaged is $3 \mathrm{~m}$ height above sea level. There are no trees or shrubs inhabiting on Ko Losin. The underwater substrate is rock base, deep down to about $40 \mathrm{~m}$. There are clefs and valleys scattering around, which provide diverse habitats for sessile marine organisms. The major sessile organisms are species of hermatypic corals and sponges.

\section{Field survey}

A scuba equipment was used to survey the islet. The depth range of this investigation was $5-30 \mathrm{~m}$ in South, Southwest, and Northwest areas. The east area of Ko Losin was not investigated due to the limitation of the current. A stratified diving from the deepest to the shallowest area of Ko Losin was made. The patterns of interaction between sponge and associated organisms were recorded and photographed during diving.
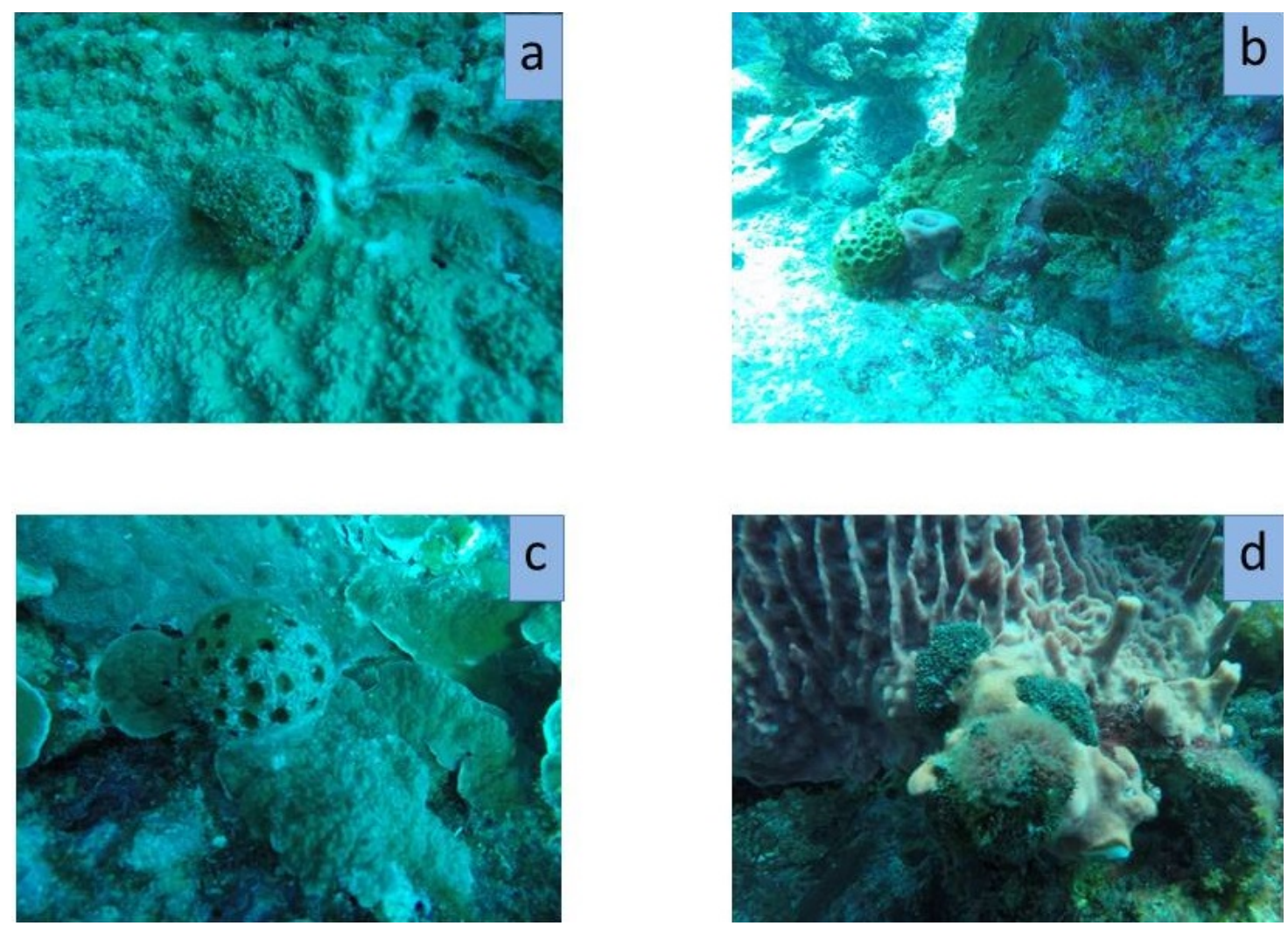

Figure 2 Types of interaction of sponge associated with organisms: (a) Gap interaction between Cinachyrellaid sponge and Montiporian coral; (b) Tissue contact interaction between Xestospongia sponge and Montiporian coral and Cinachyrellaid sponge; (c) Overgrown interaction, Cinachyrellaid sponge overgrown by Montiporian coral; (d) Overgrown interaction, Hyrtios sponge overgrow Xestospongia sponge. 
http://wjst.wu.ac.th

\section{Patterns of interaction}

The patterns of interaction between sponge and associated organisms in this study were modified from Aerts and Soest 1997. There are four categories classified. These are; gap, tissue contact, overgrown, and overgrow. Gap means there is no contact of the tissue between sponge and associated organisms. Tissue contact means that there is contact of the tissue between sponge and associated organisms. Overgrown means that the sponges are overgrown by associated organisms which caused the overgrown tissue of sponge to be shaped by the overgrow tissue of associated organisms. Overgrow means that the sponge grows over the tissue of associated organisms, including the epizoism by sponge (Figure 2).

\section{Data analysis}

The interaction patterns of six genera of commonly found sponge were recorded. Then, data were processed and were expressed in proportionate to types of interaction and types of associated organisms (Microsoft Excel 2010).

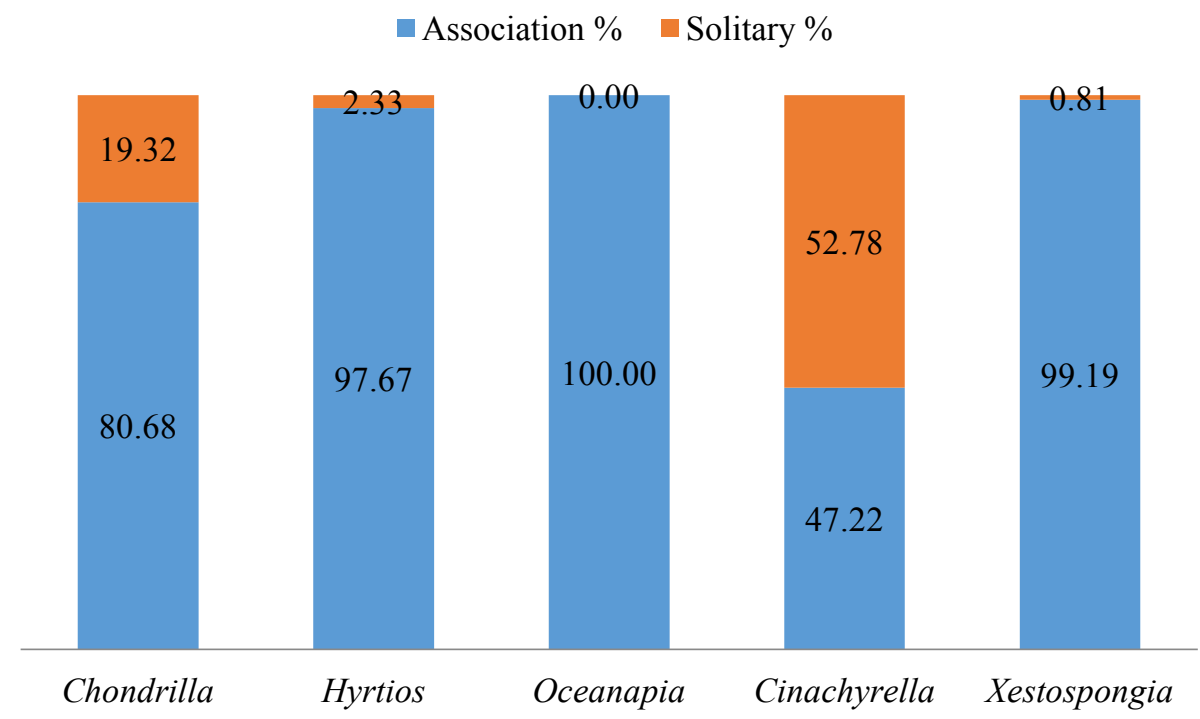

Figure 3 The proportion of living mode of sponge genera

\section{Results and discussion}

The overall sponge surveyed at Ko Losin showed that there are both solitary and association living modes. Cinachyrellaid sponge explores the highest solitary living mode (52.78\%), Chondrillid sponge (19.32\%), Hyrtios sponge (2.33\%) and Xestospongian sponge $(0.81 \%)$, respectively (Figure 3). It is noted that only one Oceanapian sponge was found in this survey. It explored associate living mode. The most frequency of sponge recorded with interaction were the following genera, Chondrilla (41.65\%); Xestospongia (30.67\%), Cinachyrella (16.96\%) and Hyrtios (10.47\%), respectively (Figure 4). However, the abundance of sponge genera varies around Ko Losin. Cinachyrellaid sponge dominated the north and northeast of Ko losin. Their abundances were 59.59 and $55.93 \%$, respectively. In the southeast, south and southwest parts of Ko Losin, the most abundant sponge genus was Chondrilla. They were $62.30 \%$ (southeast), $51.58 \%$ (south) and $62.30 \%$ (southwest). However, this was not true in the northwest of Ko Losin, where the dominant genus of sponge was obscure (Figure 5). With regard to sssociated organisms, the most frequently reported was hermatypic corals such as Montiporian coral; $47.78 \%$, Porites corals; $30.70 \%$ and Pocilloporian coral; $12.34 \%$, respectively. 


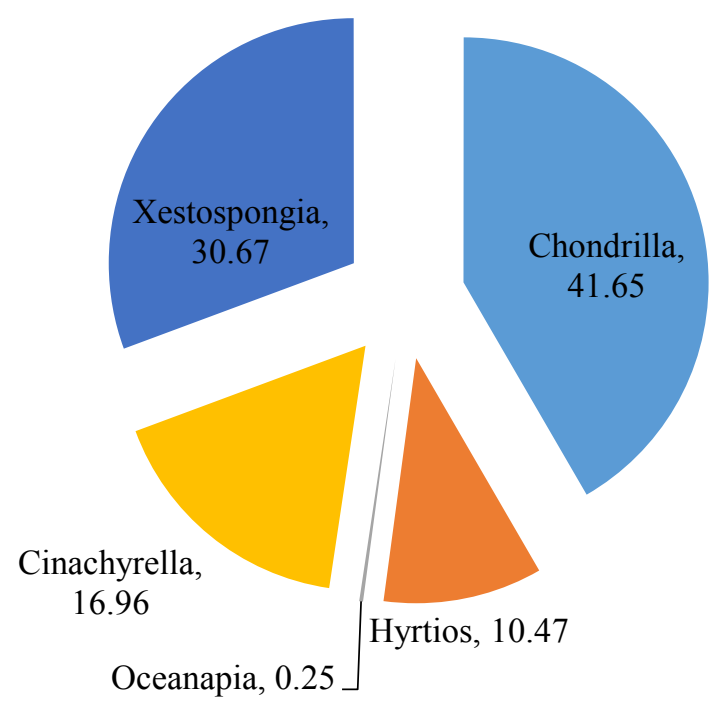

Figure 4 Percentage of sponge genera found with associated organisms.

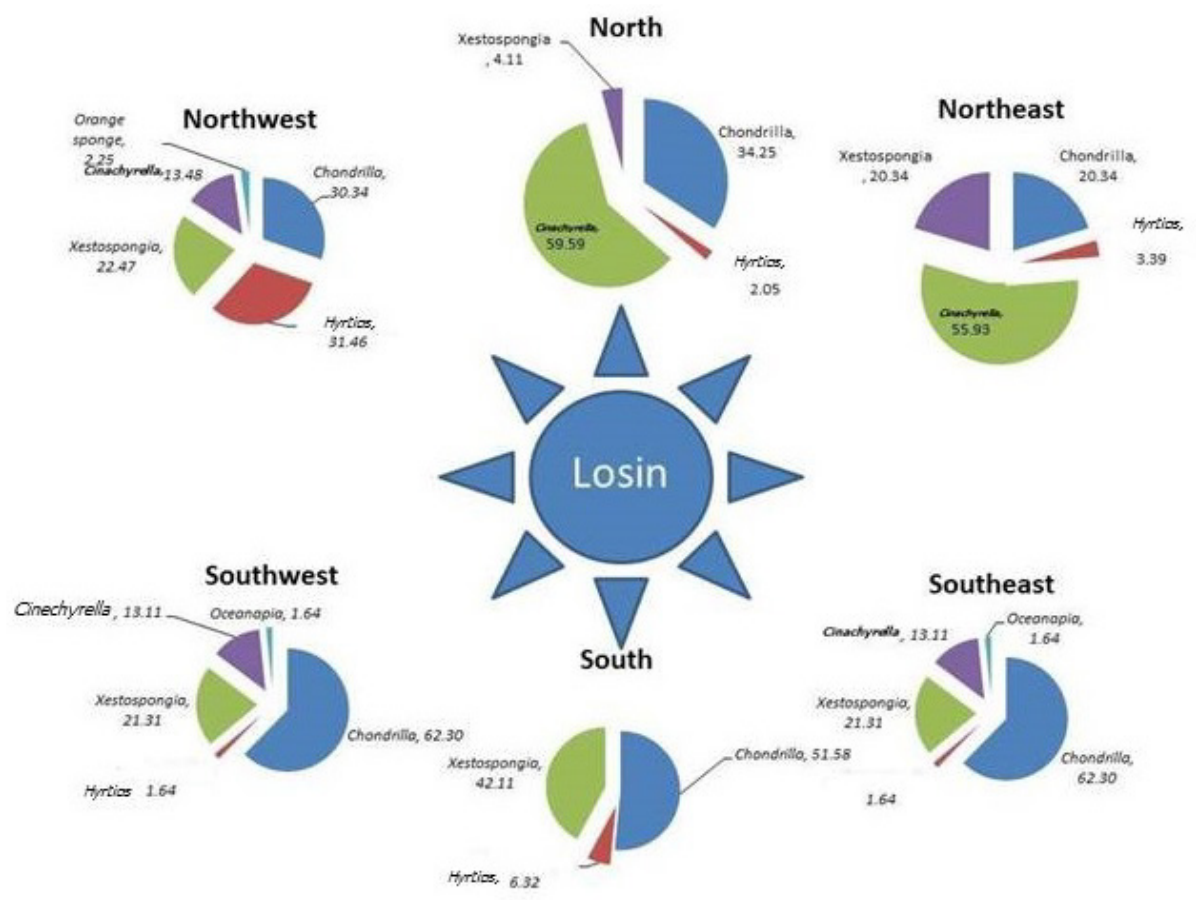

Figure 5 The percentage abundance of sponge genera around Ko Losin. 


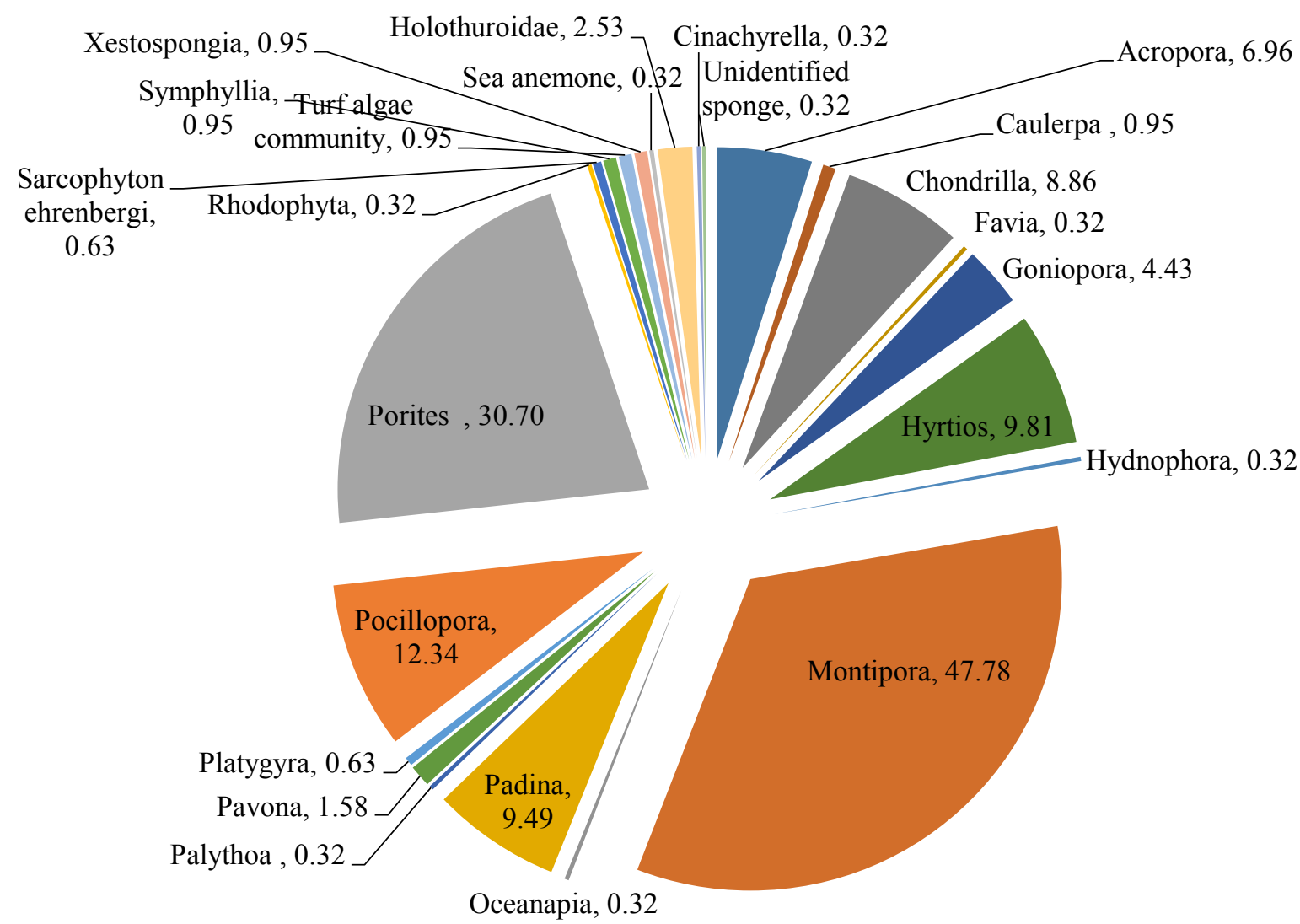

Figure 6 Percentage of overall taxa associated with sponges.

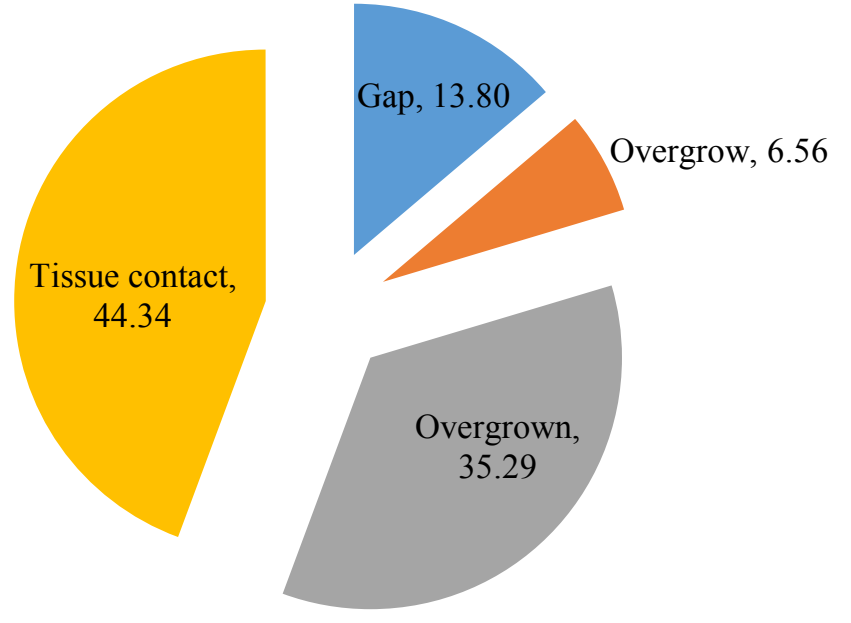

Figure 7 Overall percentage of associate Interaction of sponges. 
http://wjst.wu.ac.th

The second most frequent, whereas, were diverse in groups. They were sponges, algae and staghorn corals (Hyrtios sponge; $9.81 \%$, Padina algae; $9.49 \%$, Acroporian corals $6.96 \%$ and Chondrillid sponge; $8.86 \%$ ), respectively (Figure 6). The three fourths of overall interactions of sponge genera of Ko Losin were overgrown (35.29\%) and tissue contact (43.39\%) (Figure 7). The Gap and Overgrown interactions were the most frequently found in Chondrillid sponge (64.06 and $55.47 \%$, respectively). Whereas, Xestospongian sponge and Hyrtios sponge have made $39.20 \%$ of tissue contact and $89.29 \%$ of Overgrow interaction, respectively (Table 1). Associated organism that has dominantly made Gap interaction was Montiporian coral (43.75\% of Gap interaction). Montiporian coral, also, made major proportion of Overgrown interaction to sponge (37.50\%). In tissue contact interaction, the most frequently associated organism found was Porites coral $(25.57 \%)$. In addition, there are three slightly equal proportion groups that showed high values. They were Montiporian coral, Chondrillid sponge and Hyrtios sponge (19.98, 17.61 and 14.77 \%), respectively. However, only Xestospongian sponge has made the only high proportion of associated organisms in the overgrow interaction (Table 2).

Chondrillid sponge showed the two high values of interaction pattern as Tissue contact (43.39\%) and Overgrown (35.29\%), respectively (Figure 8). Montiporian coral was found the highest value of associated organisms of Chondrillid sponge (Figure 9). In addition, Montiporian coral has made the gap and overgrown interaction with Chondrillid sponge. Hyrtios sponge showed the highest values of interaction pattern as Overgrow (Figure 10). Porites coral was found the highest value of associated organisms of Hyrtios sponge (Figure 11). In addition, Porites coral has made an overgrow interaction with Hyrtios sponge.

Xestospongian sponge showed the highest values of interaction pattern as tissue contact (Figure 12). Montiporian coral was found the highest value of associated organisms of Xestospongian sponge (Figure 13). In addition, Montiporian coral made an Overgrown interaction with Xestospongian sponge. Cinachyrellaid sponge showed the highest values of interaction pattern as tissue contact (Figure 14). Chondrillid sponge was found the highest value of associated organisms of Cinachyrellaid sponge (Figure 15). In addition, Chondrillid sponge has made the tissue contact and overgrown interaction with Cinachyrellaid sponge.

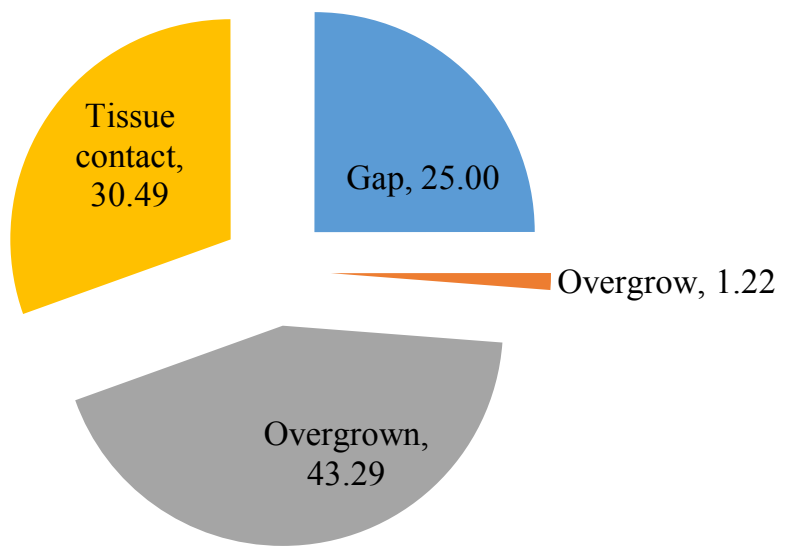

Figure 8 The percentage of interactions of Chondrillid sponge. 
http://wjst.wu.ac.th

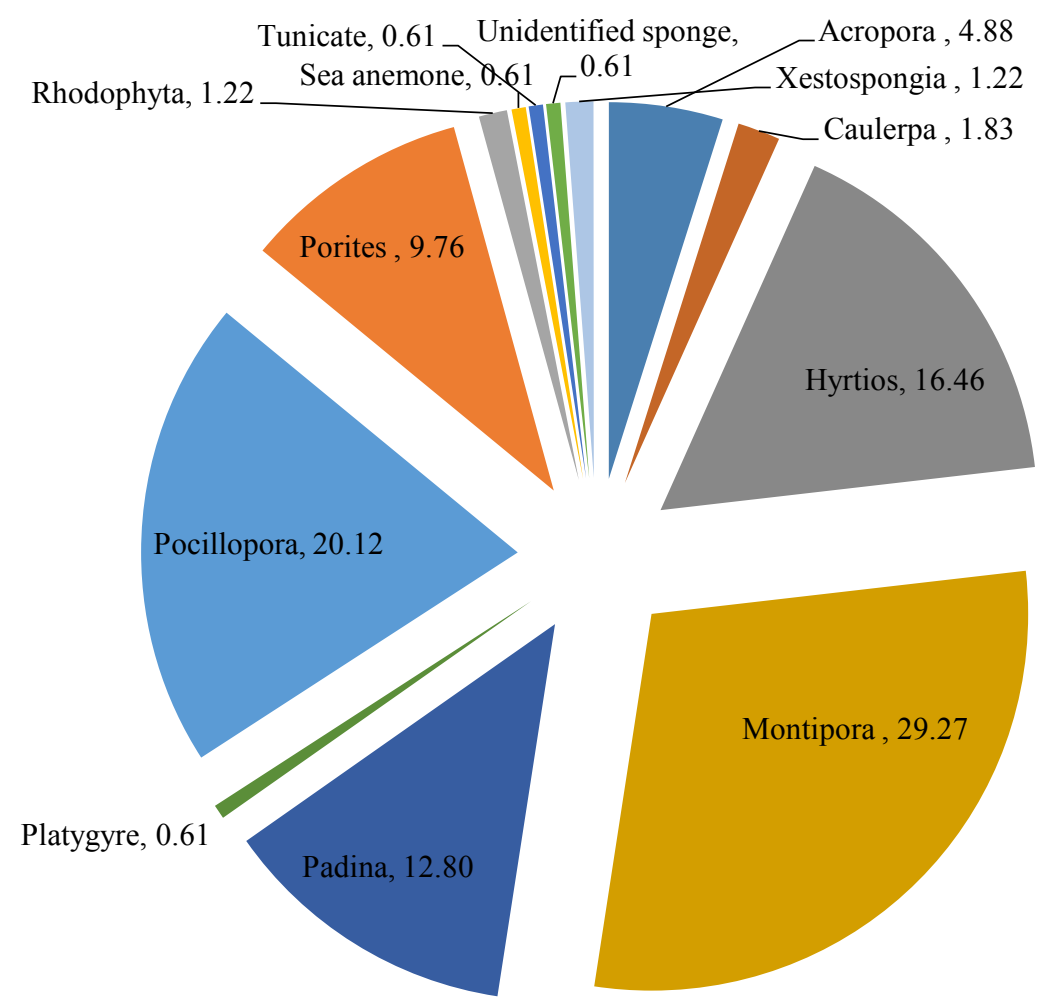

Figure 9 Percentage of organisms associated with Chondrillid sponge.

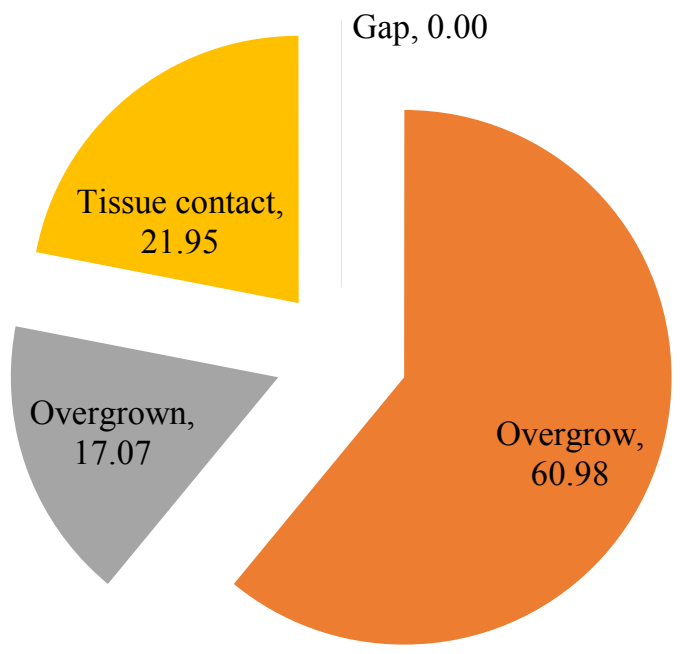

Figure 10 The percentage of interactions of Hyrtios sponge. 
http://wjst.wu.ac.th

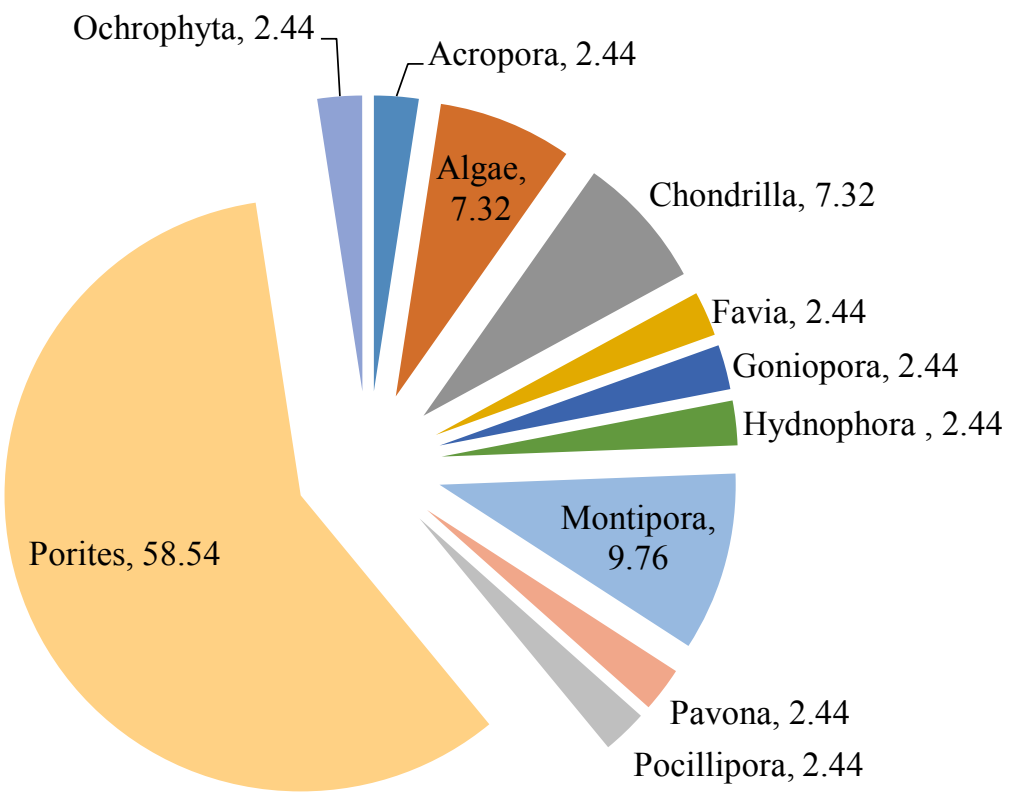

Figure 11 Percentage of organisms associated with Hyrtios sponge.

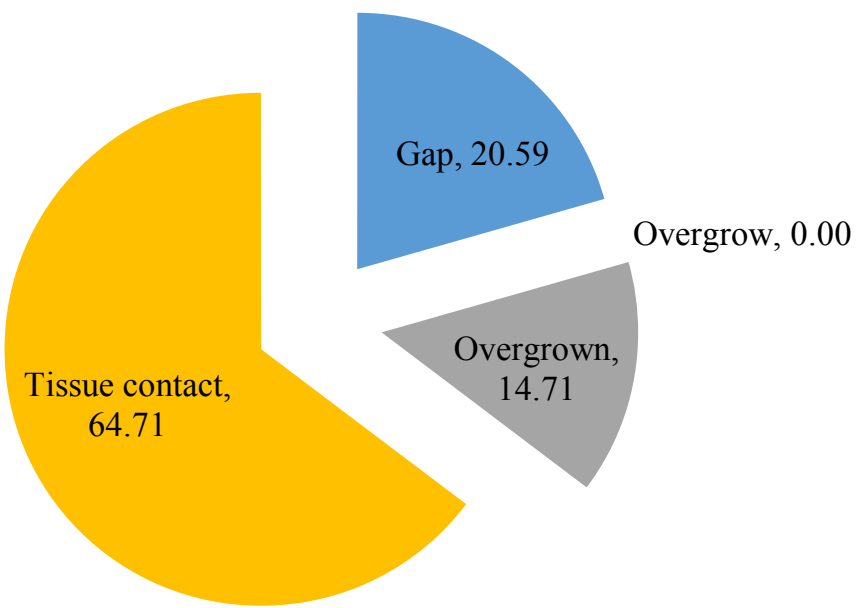

Figure 12 The percentage of interactions of Cinachyrellaid sponge. 


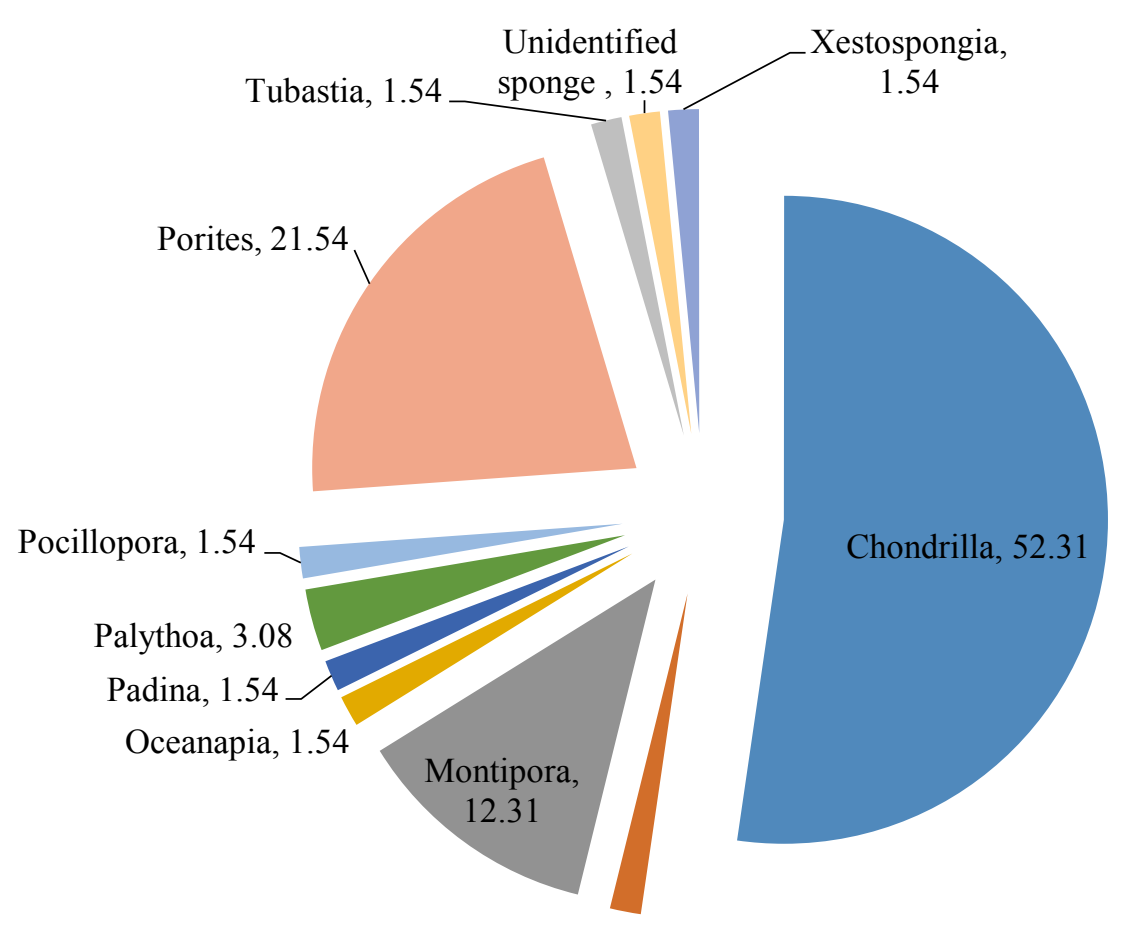

Galaxia, 1.54

Figure 13 Percentage of organisms associated with Cinachyrellaid sponge.

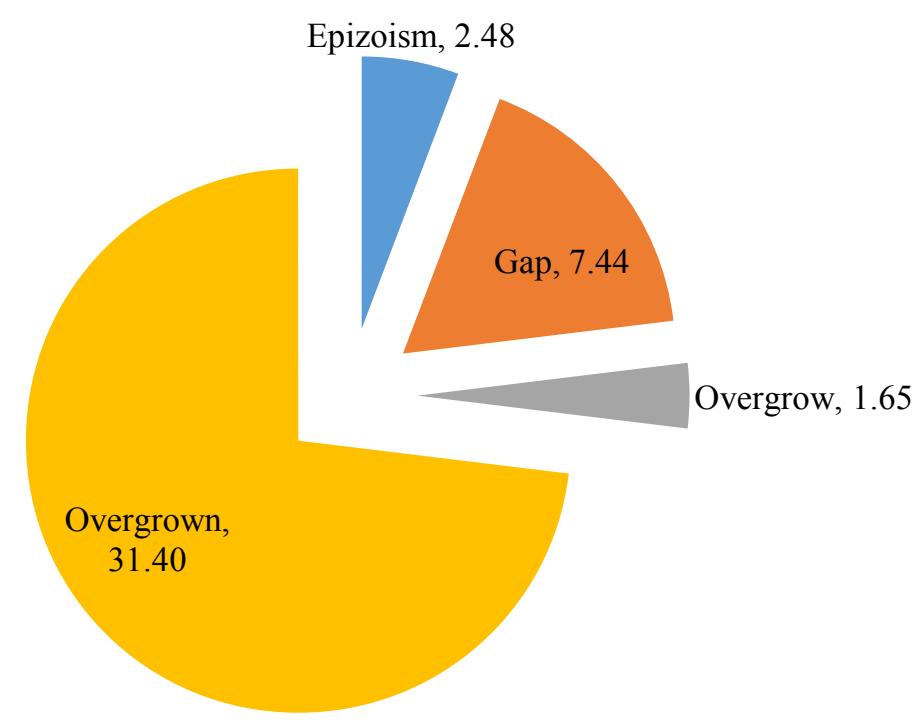

Figure 14 The percentage of interactions of Xestospongian sponge. 
http://wjst.wu.ac.th

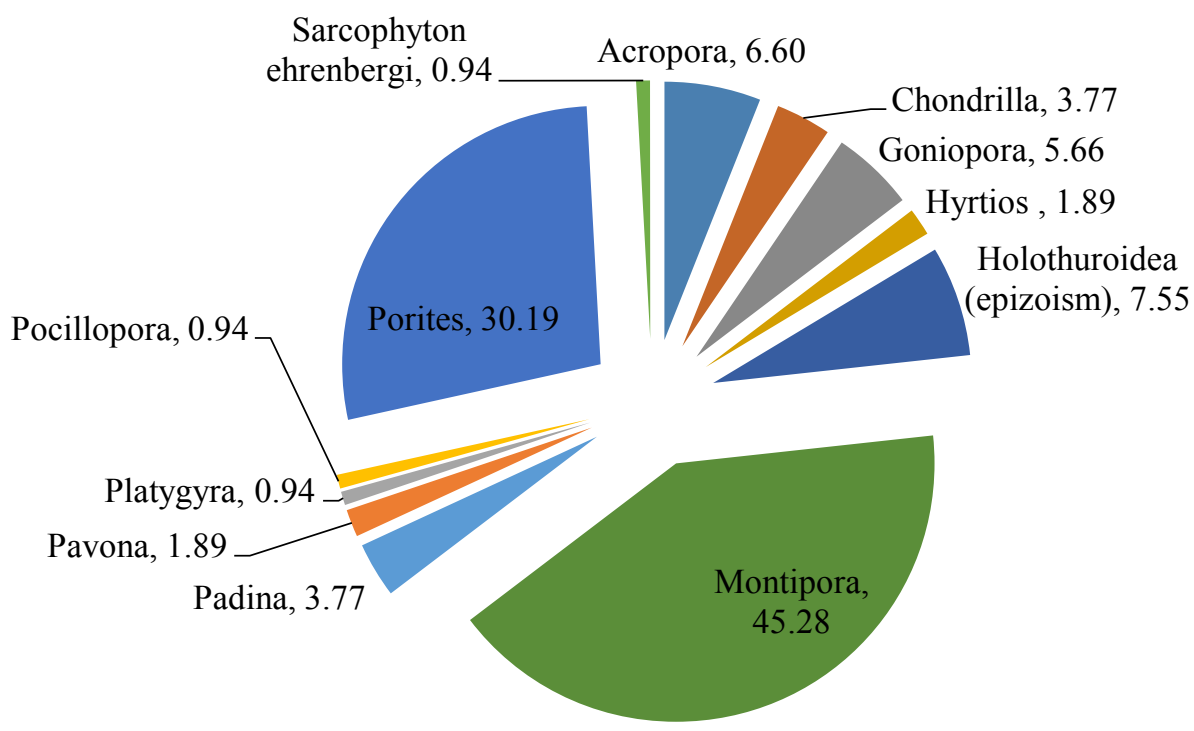

Figure 15 Percentage of organisms associated with Xestospongian sponge.

The association pattern of marine sponges and the associated organisms at Ko Losin, the less anthropogenic disturbed coral reef can be concluded as the followings. First, Tissue contact and Overgrown interactions were the most frequently found patterns. Secondly, different genus of sponges showed different patterns of interaction associated with other sessile organisms. Thirdly, the sponge community of Ko Losin is driven by physical factor, like the expected wave stress; and biological factors, such as the expected competition for space.

Table 1 The percentage of sponge genera exploring the interaction pattern with associated organism

\begin{tabular}{lcccc}
\hline Interaction patterns & Gap $(\mathbf{n}=\mathbf{6 4})$ & Overgrown $(\mathbf{n}=\mathbf{1 2 8})$ & Tissue contact $(\mathbf{n}=\mathbf{1 7 6})$ & Overgrow $(\mathbf{n}=\mathbf{2 8})$ \\
\hline Sponge Genera & $\mathbf{\%}$ & $\mathbf{\%}$ & $\mathbf{\%}$ & $\mathbf{\%}$ \\
\hline Chondrilla & 64.06 & 55.47 & 28.41 & 7.14 \\
Hyrtios & - & 7.81 & 5.68 & 89.29 \\
Oceanapia & - & 0.78 & - & - \\
Orange sponge & - & - & 1.70 & - \\
Cinachyrella & 21.88 & 3.91 & 25.00 & - \\
Xestospongia & 14.06 & 32.03 & 39.20 & 3.57 \\
- means interaction is not observed & & & \\
\hline
\end{tabular}


http://wjst.wu.ac.th

Table 2 List of associated organisms inhabiting in sponges and percentage of interactions for each associated taxa

\begin{tabular}{|c|c|c|c|c|}
\hline Interaction patterns & $\operatorname{Gap}(n=64)$ & Overgrown $(n=128)$ & Tissue contact $(n=176)$ & Overgrow $(n=28)$ \\
\hline Associated organisms & $\%$ & $\%$ & $\%$ & $\%$ \\
\hline \multicolumn{5}{|l|}{ Phylum Porifera } \\
\hline Chondrilla & 12.5 & 3.91 & 17.61 & 3.57 \\
\hline Cinachyrella & 1.56 & - & - & - \\
\hline Hyrtios & - & 2.34 & 14.77 & - \\
\hline Oceanapia & - & - & 0.57 & - \\
\hline Xestospongia & 1.56 & - & 1.14 & 89.29 \\
\hline Unidentified sponge & - & - & 1.14 & - \\
\hline \multicolumn{5}{|l|}{ Phylum Cnidaria } \\
\hline Acropora & 12.50 & 0.78 & 4.55 & - \\
\hline Favia & - & - & - & 3.57 \\
\hline Goniopora & - & - & 4.55 & - \\
\hline Hydnophora & - & - & 0.57 & - \\
\hline Montipora & 43.75 & 37.50 & 19.89 & 3.57 \\
\hline Palythoa & - & - & 1.14 & - \\
\hline Pavona & - & 0.78 & 1.14 & - \\
\hline Platygyra & 1.56 & 0.78 & - & - \\
\hline Pocillopora & 4.69 & 23.44 & 3.41 & - \\
\hline Porites & 20.31 & 2.34 & 25.57 & \\
\hline Symphyllia & - & - & 0.57 & - \\
\hline Sarcophyton ehrenbergi & - & - & 0.57 & - \\
\hline Sea anemone & - & 0.78 & - & - \\
\hline Galaxia & - & - & 0.57 & - \\
\hline Tubastia & - & - & 0.57 & - \\
\hline \multicolumn{5}{|l|}{ Phylum Chordata } \\
\hline Tunicata & - & - & 0.57 & - \\
\hline Division Rhodophyta & - & 0.78 & - & - \\
\hline Division Ochrophyta & - & 1.56 & 1.14 & - \\
\hline Padina & - & 20.31 & - & - \\
\hline \multicolumn{5}{|l|}{ Division Chlorophyta } \\
\hline Caulerpa sp. & - & 2.34 & - & - \\
\hline Turf algae community & 1.56 & 2.34 & - & - \\
\hline
\end{tabular}

- means interaction is not observed 
http://wjst.wu.ac.th

\section{Discussion}

Ko Losin is the offshore islet in the Gulf of Thailand. Its ecological profile is unique, due to the different impacted factors to other offshore islets, particularly wave action. For example, Sumpayae islet, in the northeast of Sichang island Chonbiru provience, which is affected by waves, industrial estate and urbanization showed that blue sponge (Xestospongia sp.) and sea anemone (personal survey) are abundant in the area. All sponges at Ko Losin found attached to the hard substrate. The shapes were found to be a suitable habitat. Chondrillid sponge that explored the encrust lifeform protrude the short body part into water column. Hyrtios sponge formed the small cluster of small cushion shape with broad body part attached to substrate. Cinachyrellaid sponge, the semispherical body shape, was attached to rock base. Therefore, the underneath circle area was attached to rock base. Xestospongia sponge, may be an exceptional as it exhibited in the urn or barrel shape into water column with extending attached area on substrate (this study). Sponge was thought to be the potential competitor of space with stony corals $[7,13-$ 15]. The mechanisms of competitions and the effect of competition between sponges and associated organisms were outstanding as demonstrated by Chadwick and Morrow in year, 2011 [14]. In nature, the patterns of competition of sponges and corals were shown in varieties of pattern as overgrowth, peripheral contact, tissue contact and non- contact (see detail in [3]). Pioneer filaments were also used by sponges to perforate the live tissue of corals or even induce polyp retraction and death [16]. This mechanism may result to the gap interaction in this study. In addition, the interaction between sponges and corals promoted by an aggressiveness of sponges themselves rather than physical stress that the coral faces [3]. In this study, $99.19 \%$ of Xestospongia sponge and $97.67 \%$ were found with associate sponge. Only $47.22 \%$ of Cinachyrellaid sponge was inhabited with associate organisms. Montiporian coral and Porites coral were the most frequently associated organisms to sponges. These two coral species were inferable and less aggressive in its interaction to sponges.

However, the classifications of interaction between sponges and other space competitors may differently depend on author(s) or researcher(s) point of view in the studied areas. Suchanek et al. [2], used the overgrow interaction as criteria interactions to discriminate aggressive or subordinate sponge groups. De Voogd et al. [17] have classified the interactions between sponge and their spatial competitors into 5 categories: Overgrowth of neighbor, Peripheral tissue contact, Tissue contact, Non-contact, and Overgrowth by neighbor. The classifications were also similar to this study. Overgrowth of neighbor seems as Overgrow (this study), Peripheral tissue contact and Tissue contact seem as Tissue contact (this study, but the parallel distances between sponges and the tissue contacted organisms were not measured); Non contact seems as Gap (this study, but the distances between sponges and the tissue contacted organisms were not measured). Overgrowth by neighbor seems as Overgrown (this study).

Competitive abilities among plants and animals have been studied for decades. Many studies have shown the hierarchical of competitive ability of sessile organisms [18-21]. However, the outcomes of the competition of space in marine environments are complicated. The combination of size dependent, habitat facilitation (may be through the intraspecific competition of the higher hierarchical competitive species themselves) microhabitats, ocean acidification and anthropogenic impacts are able to modify the hierarchical competitive results [22-25]. Consequences of the above combinations of interaction can lead to phase shift alone the zonation of coral reef communities [24,26]. Chemical warfare, the secondary metabolites have been proven to be the chemical defense among sessile marine organisms [10,27]. Future studies of interaction pattern of sponges and association organisms at Ko Losin should deal with the deeper inspection in the combination of physical factors on the frequency of interaction patterns, such as, wave actions and light penetration (quality and quantity).

\section{Acknowledgement}

We are deeply grateful for Walailak University, Marine and Coastal Resources Research and Development Center Lower Gulf of Thailand (MCRRDL) for the support given during the conduct of this study. 
http://wjst.wu.ac.th

\section{References}

[1] MC Diaz and K Rützler. Sponges: An essential component of Caribbean coral reefs. Bull. Mar. Sci. 2001; 69, 535-46.

[2] TH Suchanek, RC Carpenter, JD Witman and CD Harvell. Sponges as important space competitors in deep Caribbean coral reef communities. Ecol. Deep Shallow Coral Reefs 1983; 7, 55-60.

[3] LAM Aerts and RWMV Soest. Quantification of sponge/coral interactions in a physically stressed reef community, NE Colombia. Mar. Ecol. Prog. Ser. 1997; 148, 125-34.

[4] EL McLean and PM Yoshioka. Association and Interactions between Gorgonians and Sponges. In: MR Custódio, G Lobo-Hajdu, E Hajdu and G Muricy (Eds.). Porifera Research: Biodiversity, Innovation and Sustainability. Museu Nacional de Rio de Janeiro, Brasil, 2007, p. 443-8.

[5] AL Powell, LJ Hepburn, DJ Smith and JJ Bell. Patterns of sponge abundance across a gradient of habitat quality in the Wakatobi Marine Park, Indonesia. Open Mar. Biol. J. 2010; 4, 31-8.

[6] J Lam, YW Cheng, WNU Chen, HH Li, CS Chen and SE Peng. A detailed observation of the ejection and retraction of defense tissue acontia in sea anemone (Exaiptasia pallida). J. Life Environ. Sci. 2017; 5, e2996.

[7] M López-Victoria, S Zea and E Weil. Competition for space between encrusting excavating Caribbean sponges and other coral reef organisms. Mar. Ecol. Prog. Ser. 2006; 312, 113-21.

[8] JE García-Hernández, GWNM van Moorsel and BW Hoeksema. Lettuce corals overgrowing tube sponges at St. Eustatius, Dutch Caribbean. Mar. Biodivers. 2017; 47, 55-6.

[9] CG Easson, M Slattery, DM Baker and DJ Gochfeld. Complex ecological associations: Competition and facilitation in sponge-algal interaction. Mar. Ecol. Prog. Ser. 2014; 507, 153-67.

[10] JR Pawlik. The chemical ecology of sponges on caribbean reefs: Natural products shape natural systems. BioScience 2011; 61, 888-98.

[11] F Azzini, B Calcinai, C Cerrano, G Bavestrello and M Pansini. Sponges of the Marine Karst Lakes and of the Coast of the Islands of Ha Long Bay (North Vietnam). In: MR Custodia, G Lobo-Hajdu, E Hajdu and G Muricy (Eds.). Porifera Research: Biodiversity Innovation and Sustainability. Museu Nacional de Rio de Janeiro, Brasil, 2007, p. 157-64.

[12] E Mclean, K Rützler and P Pooler. Competing for space: Factors that lead to sponge overgrowth when interacting with octocoral. Open J. Mar. Sci. 2015; 5, 64-80.

[13] K Ruetzler. Sponges on coral reefs: A community shaped by competitive cooperation. Bollettino dei Museidegli Istitute Biologici dell' Universita di Genova 2004; 68, 85-148.

[14] NE Chadwick and KM Morrow. Competition among Sessile Organisms on Coral Reefs. In: Z Dubinsky and N Stambler (Eds.). Coral Reefs: An Ecosystem in Transition. Springer, Dordrecht, Netherlands, 2011, p. 347-71.

[15] J Wulff. Ecological Interactions and the distribution, abundance, and diversity of sponges. $A d v$. Mar. Biol. 2012; 61, 273-344.

[16] M López-Victoria and S Zea. Storm-mediated coral colonization by an excavating Caribbean sponge. Clim. Res. 2004; 26, 251-6.

[17] NJ de Voogd, LE Becking, BW Hoeksema, A Noor and RWMV Soest. Sponge interactions with spatial competitors in the Spermonde Archipelago. Bollettino dei Musei e degli Istituti Biologici dell Universita di Genova 2004; 68, 253-61.

[18] PK Dayton. Competition, disturbance, and community organization: The provision and subsequent utilization of space in a rocky intertidal community. Ecol. Monogr. 1971; 41, 351-89.

[19] DE Goldberg and K Landa. Competitive effect and response: Hierarchies and correlated trairs in the early stages of competition. J. Ecol. 1991; 79, 1013-30.

[20] JG Puntieri and P Pysek. Branching and competitive hierarchies in populations of Galiun aparine. Can. J. Bot. 1998; 76, 63-74.

[21] $\mathrm{MH} \mathrm{Gu,} \mathrm{T} \mathrm{Wang} \mathrm{and} \mathrm{ZK} \mathrm{Xie.} \mathrm{Competitive} \mathrm{hierarchy} \mathrm{among} \mathrm{three} \mathrm{perennial} \mathrm{grasses} \mathrm{under} \mathrm{clipping}$ and fertilization through three growing years on the eastern Qinghai-Tibetan Plateau. Proc. Environ. Sci. 2012; 13, 151-7. 
http://wjst.wu.ac.th

[22] KE Buenau, NN Price and RM Nisbet. Size dependence, facilitation, and microhabitats mediate space competition between coral and crustose coralline algae in spatially explicit model. Ecol. Model. 2012; 273-238, 23-33.

[23] KRN Anthony, JA Maynard, G Diaz-Pulido, PJ Mumby, PA Marshall, L Cao and O HoeghGuldberg. Ocean acidification and warming will lower coral reef resilience. Global Change Biol. 2011; 17, 1798-808.

[25] SK Roth, A Powell, DJ Smith, F Roth and B Schierwater. The highly competitive ascidian Didemnum sp. threatens coral reef communities in Wakatobi Marine National Park, Southern Sulawesi, Indonesia. Regin. Stud. Mar. Sci. 2018; 24, 48-54.

[24] ICS Cruz, LG Water, RKP Kikuchi, ZMAN Leão and A Turra. Marginal coral reefs show high susceptibility of phase shift. Mar. Pollut. Bull. 2018; 135, 551-61.

[26] ICS Cruz, VH Meira, RKP de Kikuchi and JC Creed. The role of competition in the phase shift to dominance of the zoanthid Palythoa cf. variabilis on coral reefs. Mar. Environ. Res. 2016; 115, 2835.

[27] TL Loh and JR Pawlik. Chemical defenses and resource trade-offs structure sponge communities on Caribbean coral reefs. Proc. Natl. Acad. Sci. 2014; 111, 4151-6. 